\title{
TYPOLOGY OF LINGUISTIC BORROWING IN THE WOLOF LANGUAGE
}

\author{
Alioune Badara Thiam \\ Gaston Berger University, GERAHA, Saint-Louis
}

\begin{abstract}
This paper offers the results of a typological analysis of loanwords in the Wolof language following the methodology applied by Haspelmath \& Tadmor in their Loanword Typology Project (LWT). On the basis of a representative sample of the world's languages these authors compiled the World Loanword Database (WOLD) and carried out a comparative analysis of the loanword profile of 41 languages focusing on 1460 lexical meanings grouped into 24 semantic fields. Since the Wolof language was not included in their typological analysis as a recipient language, the following text is meant as a further contribution to the LWT project. On the whole, the Wolof language conforms to the general principles established by Haspelmath and Tadmor, although some minor departures are also observed.
\end{abstract}

KEYwORDs: Linguistic borrowing, loanwords typology, Wolof language.

\section{TIPOLOGÍA DE LOS PRÉSTAMOS LINGÜÍSTICOS \\ EN LA LENGUA WOLOF}

\section{RESUMEN}

Este artículo ofrece los resultados de un análisis tipológico de los préstamos en la lengua wolof, siguiendo la metodología aplicada por Haspelmath y Tadmor en su proyecto llamado Loanword Typology (LWT). Basándose en un corpus representativo de las lenguas del mundo, estos autores desarrollaron una base de datos denominada World Loanword Database (WOLD) y llevaron a cabo un análisis comparativo de una muestra de 41 lenguas, basado en una lista fija de 1460 significados léxicos repartidos en 24 campos semánticos. Al constatar que el wolof no está incluido en su análisis tipológico como lengua receptora, el presente artículo pretende ser una contribución al proyecto LWT. En conjunto global, la lengua wolof confirma los principios generales establecidos por Haspelmath y Tadmor, aunque se observan algunas discrepancias menores.

Palabras clave: Préstamos lingüísticos, tipología lingüística, lengua Wolof.

DOI: https://doi.org/10.25145/j.recaesin.2020.80.08

Revista Canaria de Estudios Ingleses, 80; April 2020, pp. 145-159; ISSN: e-2530-8335 


\section{INTRODUCTION}

Wolof, the majority ethnic group and language in Senegal, has been lexically enriched, as a result of its many historical contacts with other local and foreign languages. Indeed, as of the $11^{\text {th }}$ century, between 1061 and 1062, the Almoravids started the first jihad (holy war) among the sub-Saharan populations that subjugated Islam. Then came the European Colonizers, especially France, from the $15^{\text {th }}$ century through the triangular trade and evangelization. Due to colonization, this prolonged contact with the local populations that cohabit in a multilingual situation, has had very significant sociolinguistic and cultural repercussions throughout the country. Consider that Senegal has an ethnolinguistic diversity reflected in the presence of almost 40 languages in correspondence to as many ethnic groups. This phenomenon of contact, which has been produced and reflected above all on the linguistic level, has got an impact on local languages, especially Wolof, which has seen its lexical heritage enriched by multiple borrowings.

But why is there a need to import words from other languages if each language has "unlimited" lexical innovation mechanisms and techniques incorporated into its own system, enabling them to name any abstract or physical novelty, foreign or local, that they discover?

To such a question, Martin Haspelmath \& Uri Tadmor tried to answer, applying an extensive approach based on "the classical methods of linguistic typology on performance", following these steps:

- Choosing a sample of 41 languages representative of the world's linguistic diversity;

- Collecting the types of borrowings found in these languages, based on a fixed list of 1,460 lexical meanings spread over 24 semantic fields;

- Attempting to draw provisional general conclusions about the languages of the sample.

The results obtained were used to formulate the following three hypotheses which should serve as general principles of "universal" validity for all languages:

1. Names are easier to import than verbs.

2. There is less likelihood of borrowing with terms referring to body parts.

3. Terms designating new artifacts are more prone to borrowing.

This work based on a thorough analysis of a corpus consisting of more than 3,500 borrowings, aims at verifying the relevance for Wolof (a language not included in Haspelmath \& Tadmor's sample as a recipient language) of the general principles applicable to the lexical borrowings resulting from the LWT (Loanword Typology) project. The corpus was collected from a variety of sources. These are first of all lexicological ones such as the Wolof-French and FrenchWolof dictionary by Jean Léopold Diouf and Mamadou Cissés French-Wolof dictionary. In addition, we also draw items from the books by Faidherbe and 
Dumont. To complete Arabic borrowings, the Koranic text was the main source of more than 170 borrowings. Some borrowings from English were taken from the Wolof-English dictionary of the American Peace Corps of The Gambia and the Gambian Wolof-English dictionary by David Percy Gamble. With regard to local languages, the fieldwork has been completed with other empirical sources, in particular radio and television programs, sitcoms in wolof, daily conversations, etc. All the sources have been reinforced by my status as a native speaker of Wolof in addition to a good knowledge of French, English and Arabic, i.e. languages which provide most of the loans in Wolof.

However, before drawing the conclusions we have reached, it is necessary to carry out a contrasting analysis of LWT and Wolof loanwords, with the aim of establishing a comparison between both studies. Indeed, after an extensive analysis of the processes of linguistic change by contact with languages, the authors of the LWT came up with conclusive results that we compared to those obtained with Wolof in order to corroborate or refute the hypotheses made by the project.

\section{LWT VS WOLOF LANGUAGE BORROWINGS}

Starting from the fact that the "borrowing phenomenon is universal", since all languages of the world borrow words from other languages, Tadmor (55) asked the following question: what makes languages prone to borrowing? His research led him to note the existence of 4 levels of language performance: very high (more than $50 \%$ of total loanwords), high (between 25 and 50\%), medium (between 10 and $25 \%$ ) and low (less than $10 \%$ ).

Table 1 shows the level of performance of each of the 41 LWT languages from highest to lowest.

Tadmor advances two main reasons to explain this difference in levels of performance between the different languages of the project. The first reason is of chronological nature: the more a language has a very long written history, the more contacts it has throughout its history, the more prone it is to borrowings; whereas the new languages, due to a lack of written tradition, need even more time to be able to take a large number of borrowings. That is to say, when a language is little studied little will be known about its history and therefore about its loanwords. As shown in table 1, the language with the highest degree in loans turns out to be Selice Romani. This minority language is actually a dialect spoken by some 1,350 speakers in a village in southern Slovakia, which for over 8 centuries has lived under the linguistic dominance of other more powerful languages such as Slovak or Hungarian that most speakers have a good command of, especially the young population. This sociolinguistic situation is favorable to the incorporation of many borrowings in the case of the Romani that lives a constant linguistic pressure on the part of the dominant languages. On the other hand, languages with a lesser degree of performance, such as Mandarin Chinese, spoken by almost a billion speakers, mostly monolingual, and whose command of other languages has been exerted for thousands of years, have almost no need to import words from other languages. 
TABLE 1: LEVEL OF PERFORMANCE OF THE 41 LWT LANGUAGES (TADMOR 56-57)

\begin{tabular}{|c|c|c|c|c|}
\hline BORROWING TYPE & LANGUAGES & No OF WORDS & No OF LOANWORDS & \% OF LOANWORDS \\
\hline \multirow{2}{*}{ Very high borrowers } & Selice Romani & 1431 & 898 & $62.7 \%$ \\
\hline & Tarifiyt Berber & 1526 & 789 & $51.7 \%$ \\
\hline \multirow{17}{*}{ High borrowers } & Gurindji & 842 & 384 & $45.6 \%$ \\
\hline & Romanian & 2137 & 894 & $41.8 \%$ \\
\hline & English & 1504 & 617 & $41.0 \%$ \\
\hline & Saramaccan & 1089 & 417 & $38.3 \%$ \\
\hline & Ceq Wong & 862 & 319 & $37.0 \%$ \\
\hline & Japanese & 1975 & 689 & $34.9 \%$ \\
\hline & Indonesian & 1942 & 660 & $34.0 \%$ \\
\hline & Bezhta & 1344 & 427 & $31.8 \%$ \\
\hline & Kildin Saami & 1336 & 408 & $30.5 \%$ \\
\hline & ImbaburaQuechua & 1158 & 350 & $30.2 \%$ \\
\hline & Archi & 1112 & 328 & $29.5 \%$ \\
\hline & Sakha & 1411 & 409 & $29.0 \%$ \\
\hline & Vietnamese & 1477 & 415 & $28.1 \%$ \\
\hline & Swahili & 1610 & 447 & $27.8 \%$ \\
\hline & Yaqui & 1379 & 366 & $26.5 \%$ \\
\hline & Thai & 2063 & 539 & $26.1 \%$ \\
\hline & Taquia & 1123 & 291 & $25.9 \%$ \\
\hline \multirow{18}{*}{ Average borrowers } & Lower Sorbian & 1671 & 374 & $22.4 \%$ \\
\hline & Hausa & 1452 & 323 & $22.2 \%$ \\
\hline & Mapudungun & 1236 & 274 & $22.2 \%$ \\
\hline & White Hmong & 1290 & 273 & $21.2 \%$ \\
\hline & Kanuri & 1427 & 283 & $19.8 \%$ \\
\hline & Dutch & 1513 & 289 & $19.1 \%$ \\
\hline & Malagasi & 1526 & 267 & $17.5 \%$ \\
\hline & Zinacantán Tzotzil & 1217 & 195 & $16.0 \%$ \\
\hline & Wichí & 1187 & 188 & $15.8 \%$ \\
\hline & Q'eqchi' & 1774 & 266 & $15.0 \%$ \\
\hline & Iraqw & 1117 & 162 & $14.5 \%$ \\
\hline & Kali'na & 1110 & 156 & $14.0 \%$ \\
\hline & Hawaiian & 1245 & 169 & $13.6 \%$ \\
\hline & Oroqen & 1138 & 137 & $12.0 \%$ \\
\hline & Hup & 993 & 114 & $11.5 \%$ \\
\hline & Gawwada & 982 & 111 & $11.3 \%$ \\
\hline & Seychelles Creole & 1879 & 201 & $10.7 \%$ \\
\hline & Otomi & 2158 & 231 & $10.7 \%$ \\
\hline
\end{tabular}




\begin{tabular}{lllll}
\hline \multirow{3}{*}{ Low borrowers } & Ket & 1030 & 100 & $9.7 \%$ \\
\cline { 2 - 5 } & Manange & 1009 & 84 & $8.3 \%$ \\
\cline { 2 - 5 } & Old High German & 1203 & 70 & $5.8 \%$ \\
\cline { 2 - 5 } & Mandarin Chinese & 2042 & 25 & $1.2 \%$ \\
\hline
\end{tabular}

Table 2 highlights the main sociolinguistic circumstances that explain the difference in performance between Mandarin Chinese and Selice Romani.

\begin{tabular}{ll}
\hline \multicolumn{1}{c}{ TABLE 2: SOCIOLINGUISTIC CIRCUMSTANCES CONDITIONING } \\
BORROWING (TADMOR 58)
\end{tabular}

If we apply to Wolof the sociolinguistic characteristics of the LWT to measure its borrowing rate, we realize from the outset that Wolof is found between Selice Romani and Mandarin Chinese, as it shares 5 out of the 9 characteristics with both, as shown in table 3 below.

\begin{tabular}{ll}
$\begin{array}{l}\text { TABLE 3: SOCIOLINGUISTIC CIRCUMSTANCES CONDITIONING BORROWING IN WOLOF } \\
\text { (NON-RELEVANT FEATURES FOR WOLOF LANGUAGE HAVE BEEN CROSSED OUT) }\end{array}$ \\
\hline \multicolumn{1}{c}{ SELICE ROMANI } & \multicolumn{1}{c}{ MANDARIN CHINESE } \\
\hline Universal multilingüism & Almost no bilingualism \\
\hline Minority langutage- & Majority language \\
\hline Soeiopolitieally marginalized & Sociopolitically dominant \\
\hline Retatively short history & Relatively long history \\
\hline Prolongettabsence of hometant & Prolonged presence in homeland \\
\hline Permissivity with respect to the Purism & Purism \\
\hline Not standardized & Highly standardized \\
\hline Well-studied contact language & Little studied contact language \\
\hline Well-known donor languages & Some little-known donor languages \\
\hline
\end{tabular}


Based on the main characteristics of Wolof, we find out that this language does not meet the criteria of Level 1 (very high, i.e. Selice Romani) or Level 4 (low, i.e. Mandarin Chinese). As these two levels are excluded, it remains to classify Wolof language between level 2 (high) and level 3 (medium). Level 2 is also ruled out if we consider the percentage of borrowing that characterizes languages belonging to this level (25\% and 50\%).

As a result, Wolof, which totals $21.1 \%$ (see table 11 below) in terms of borrowing ranks at the average level 3. However, it is important to highlight the concepts of donor language and standardized language.

In fact, as far as Wolof is concerned, donor foreign languages are clearly identified. But when it comes to local languages, the problem lies in the difficulty of knowing which language has lent/borrowed to/from the other, as the languages in question have always shared the same geographical territory, and this context has favoured intense intercultural exchanges for centuries to the extent that is virtually impossible to detect the source of borrowing. This situation is mainly due to the lack of written documents narrating the history of languages in Senegal's sociolinguistic landscape. As far as the standardization of the Wolof language is concerned, several official decrees regulate it from 1971 to 2005 . The decrees are related to transcription, spelling and separation of words. They also pursue the objective of codifying not only the Wolof language but also the other local languages claiming the same status as the Wolof. It is worth emphasizing that a great majority of the Senegalese population can neither read nor write in Wolof: more than $87 \%{ }^{1}$ of Wolof speakers can neither read nor write in this language. As $54 \%^{2}$ of the population is educated in French, written communications are mostly done in either French or in Arabic. The latter plays a religious role in the country where the population is predominantly Muslim at $95 \%{ }^{3}$. From a glottopolitical point of view, national languages still play a very marginal role. Their role is essentially limited to the literacy of rural people so that they can read and write in their mother tongue. French is still the only official language in the country, even though the expansion and visibility of Wolof are undeniable.

${ }^{1}$ On the literacy level of the Senegalese population in local languages, $c f$. Recensement Général de la Population et de l'Habitat, de l'Agriculture et de l'Elevage ['General Census of Population and Housing'].

2 Source: Recensement Général de la Population et de l'Habitat, de l'Agriculture et de l'Elevage.

3 Cf. Triaud. 


\section{CONTRASTIVE ANALYSIS OF LWT AND WOLOF BORROWING ACCORDING TO SEMANTIC WORD CLASS}

\subsection{CONTENT WORDS vS FUNCTION WORDS}

Analyzing the cases of borrowings encountered in the project's languages, Tadmor retains 5 different categories: nouns, verbs, adjectives, adverbs and function words that he gathers into 2 main classes, namely, content words and function words. According to the results obtained, only three languages -White Hmong (with 22.4\% of function words against $21.1 \%$ of lexical words), Hup (16.6\% against $11.1 \%)$ and Wich (15.5\% against $21.5 \%)$ - do not confirm the hypothesis that languages adopt more content words than function words.

\begin{tabular}{lccc}
\hline \multicolumn{5}{c}{ TABLE 4: BORROWED CONTENT WORDS AND FUNCTION WORDS: } \\
\multicolumn{1}{c}{$\begin{array}{c}\text { TOTAL FIGURES } \\
\text { CATEGORY }\end{array}$} & No OF WORDS & LOANWORDS & \% OF LOANWORDS \\
\hline Content words & 53446 & 13446 & $25.2 \%$ \\
\hline Function words & 4071 & 492 & $12.1 \%$ \\
\hline Total & $\mathbf{5 7 5 1 7}$ & $\mathbf{1 3 9 3 8}$ & $\mathbf{2 4 . 2 \%}$ \\
\hline
\end{tabular}

With regard to Wolof, given the low number of registered function words (32) in relation to the total number of borrowings in our corpus (3629), representing a percentage of only $1.9 \%$, it is clear that Wolof speakers have not taken many function words from languages in contact. This may be due to the marginal bilingualism of Wolof speakers. The observations of language practices in Senegal show us that the majority of speakers having Wolof as their mother tongue do not practice another local language.

\begin{tabular}{lcc}
\hline \multicolumn{3}{c}{ TABLE 5: WOLOF BORROWED CONTENT WORDS AND FUNCTION WORDS } \\
\hline \multicolumn{1}{c}{ SEMANTIC WORD CLASS } & No OF LOANWORDS & \% OF LOANWORDS \\
\hline Content words & 3597 & $99.1 \%$ \\
\hline Function words & 32 & $0.9 \%$ \\
\hline Total & $\mathbf{3 6 2 9}$ & $\mathbf{1 0 0 \%}$ \\
\hline
\end{tabular}

\subsection{NOUNS VS VERBS}

In the following tables 6 and 7, the results obtained by Tadmor concerning the behavior of the borrowings with respect to the semantic word class, will give us the key to test our first hypothesis. According to the author (Table 6), the number of nouns doubles the number of verbs, i.e. $31 \%$ versus $14 \%$ because "things and concepts are easily adopted across culture" (61). 
TABLE 6: BORROWING BY SEMANTIC WORD CLASS: TOTAL FIGURES BY TADMOR (61)

\begin{tabular}{lccc}
\hline SEMANTIC WORD ClASS & No OF WORDS & LOANWORDS & \% OF LOANWORDS \\
\hline Nouns & 34355 & 10712 & $31.2 \%$ \\
\hline Adjectives and adverbs & 5284 & 803 & $15.2 \%$ \\
\hline Verbs & 13808 & 1932 & $14.0 \%$ \\
\hline Total of content words & $\mathbf{5 3 4 4 6}$ & $\mathbf{1 3 4 4 6}$ & $\mathbf{2 5 . 2} \%$ \\
\hline
\end{tabular}

Comparing these data with those of Wolof, we can confirm this first hypothesis of the present study, as the percentage of names is almost triple than that of verbs. Consider Table 7 which distributes borrowings according to the different semantic categories.

\begin{tabular}{lcc}
\hline \multicolumn{2}{c}{ TABLE 7: WOLOF BORROWINGS BY SEMANTIC WORD CLASS } \\
\hline \multicolumn{1}{c}{ SEMANTIC WORD Class } & No OF LOANWORDS & \% OF LOANWORDS \\
\hline Nouns & 2492 & $65.4 \%$ \\
\hline Verbs & 819 & $22.6 \%$ \\
\hline Adjectives & 278 & $7.9 \%$ \\
\hline Adverbs & 117 & $3.2 \%$ \\
\hline Function words & 32 & $0.9 \%$ \\
\hline Total & $\mathbf{3 6 2 9}$ & $\mathbf{1 0 0} \%$ \\
\hline
\end{tabular}

Table 8, which we discuss below, presents the percentages of nouns and verbs that each language contributed to the LWT project. With the exception of Gurindji (with $48.8 \%$ of nouns versus $49.7 \%$ of verbs) and Saramacan (with $44 \%$ of verbs versus $37.1 \%$ of nouns), in all the other languages of the project nouns outnumber verbs. In the case of Saramacan, the result is due to "the partial relexification of Saramaccan by Portuguese" (Tadmor 63). This general preference can be explained by the fact "the more isolating the recipient language, the less morphosyntactic adaptation is necessary for borrowing verbs as such; conversely, the more synthetic language, the more adaptation is required. It is much easier to borrow than it is to synthesize languages" (Tadmor 63). Yet, according to Tadmor quoting Kossmann, this phenomenon does not always depend on linguistic factors, but rather on social reasons. The example of Mandarin Chinese, which despite being a highly insulating language has no verbal borrowing in the LWT corpus, and the case of Berber which has adopted several verbs as a substantially synthetic language -because of the strong influence of Arab language for centuries, tend to corroborate this linguistic fact. 


\begin{tabular}{|c|c|c|c|}
\hline \multicolumn{4}{|c|}{ TABLE 8: LOAN NOUNS AND LOAN VERBS BY PROJECT LANGUAGE (TADMOR 62) } \\
\hline LANGUAGES & $\%$ OF LOAN NOUNS & $\%$ OF LOAN VERBS & $\begin{array}{l}\text { LOAN NOUN TO LOAN } \\
\text { VERB RATIO }\end{array}$ \\
\hline Zinacantán Tzotzil & $24.1 \%$ & $0.6 \%$ & 37.5 \\
\hline Takia & $37.7 \%$ & $3.2 \%$ & 11.8 \\
\hline Iraqw & $23.6 \%$ & $2.1 \%$ & 11.3 \\
\hline Wichí & $23.1 \%$ & $2.7 \%$ & 8.4 \\
\hline Otomi & $17.0 \%$ & $2.2 \%$ & 7.6 \\
\hline Bezhta & $44.4 \%$ & $6.0 \%$ & 7.5 \\
\hline Oroqen & $18.6 \%$ & $2.8 \%$ & 6.7 \\
\hline Kali'na & $21.1 \%$ & $3.6 \%$ & 5.8 \\
\hline Old HIgh German & $9.0 \%$ & $1.7 \%$ & 5.4 \\
\hline Q'eqchi' & $23.0 \%$ & $4.8 \%$ & 4.8 \\
\hline Hausa & $31.2 \%$ & $7.0 \%$ & 4.4 \\
\hline Hawaiian & $19.3 \%$ & $5.1 \%$ & 3.8 \\
\hline Manange & $12.3 \%$ & $3.3 \%$ & 3.7 \\
\hline Yaqui & $37.3 \%$ & $10.1 \%$ & 3.7 \\
\hline Gawwada & $16.9 \%$ & $4.6 \%$ & 3.6 \\
\hline Archi & $40.6 \%$ & $11.7 \%$ & 3.5 \\
\hline Dutch & $26.3 \%$ & $7.5 \%$ & 3.5 \\
\hline Seychelles Creole & $14.6 \%$ & $4.1 \%$ & 3.5 \\
\hline Ket & $13.6 \%$ & $4.0 \%$ & 3.4 \\
\hline Lower Sorbian & $30.7 \%$ & $9.0 \%$ & 3.4 \\
\hline Malagasi & $23.9 \%$ & $7.0 \%$ & 3.4 \\
\hline Mapudungun & $31.3 \%$ & $10.1 \%$ & 3.1 \\
\hline Sakha & $40.0 \%$ & $12.8 \%$ & 3.1 \\
\hline Kanuri & $26.7 \%$ & $8.7 \%$ & 3.0 \\
\hline Imbura Quechua & $43.1 \%$ & $15.5 \%$ & 2.8 \\
\hline Indonesian & $43.7 \%$ & $17.2 \%$ & 2.5 \\
\hline Japanese & $43.2 \%$ & $19.9 \%$ & 2.2 \\
\hline Swahili & $34.3 \%$ & $16.0 \%$ & 2.1 \\
\hline Kildin Saami & $38.0 \%$ & $19.1 \%$ & 2.0 \\
\hline Thai & $32.3 \%$ & $16.3 \%$ & 2.0 \\
\hline Hup & $13.8 \%$ & $8.3 \%$ & 1.7 \\
\hline Selice Romani & $75.6 \%$ & $45.1 \%$ & 1.7 \\
\hline Romanian & $50.2 \%$ & $32.1 \%$ & 1.6 \\
\hline English & $48.0 \%$ & $34.1 \%$ & 1.4 \\
\hline Tarifiyt Berber & $56.1 \%$ & $44.1 \%$ & 1.3 \\
\hline
\end{tabular}




\begin{tabular}{lccc}
\hline Ceq Wong & $41.6 \%$ & $32.1 \%$ & 1.3 \\
\hline Vietnamese & $31.3 \%$ & $25.0 \%$ & 1.3 \\
\hline White Hmong & $21.5 \%$ & $18.8 \%$ & 1.1 \\
\hline Gurindji & $48.8 \%$ & $49.7 \%$ & 1.0 \\
\hline Saramaccan & $37.1 \%$ & $44.0 \%$ & 0.8 \\
\hline Mandarin Chinese & $1.9 \%$ & $0.0 \%$ & - \\
\hline Total & $\mathbf{3 1 . 2} \%$ & $\mathbf{1 4 . 0} \%$ & $\mathbf{2 . 2}$ \\
\hline
\end{tabular}

If we take the data of each donor language in the case of Wolof, we also find that none of them gave more verbs or other categories of words than nouns (Table 9), which confirms again our hypothesis 1.

\begin{tabular}{|c|c|c|c|c|c|c|c|c|c|c|c|c|}
\hline \multicolumn{13}{|c|}{$\begin{array}{l}\text { TABLE 9: WOLOF BORROWING CONTENT WORDS VS } \\
\text { FUNCTION WORDS BY DONOR LANGUAGES }\end{array}$} \\
\hline & 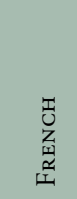 & 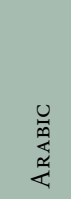 & 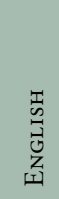 & 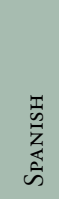 & 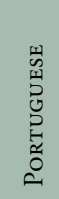 & 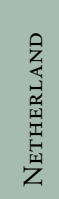 & $\begin{array}{l}\stackrel{\alpha}{4} \\
5 \\
5\end{array}$ & 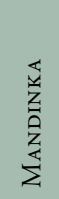 & 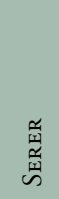 & ن & 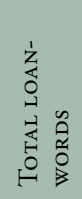 & 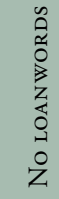 \\
\hline Nouns & 44.9 & 16.3 & 1.8 & - & 0.9 & 0.1 & 0.6 & 0.6 & 0.1 & - & 65.4 & 34.6 \\
\hline Verbs & 17.5 & 5.3 & 0.4 & 0.1 & - & - & - & 0.2 & - & - & 22.6 & 77.4 \\
\hline Adjectives & 7.5 & 2.0 & 0.1 & - & - & - & - & - & - & - & 7.9 & 92.1 \\
\hline Adverbs & 3.2 & 3.1 & - & - & 0.0 & - & 0.0 & - & - & - & 3.2 & 96.8 \\
\hline Function words & 1.9 & - & - & 0.0 & - & - & - & - & - & - & 1.9 & 98.1 \\
\hline Total & 15.0 & 5.3 & 0.5 & 0.0 & 0.2 & 0.0 & 0.1 & 0.0 & 0.0 & 0.0 & 21.1 & 78.9 \\
\hline
\end{tabular}

\section{ANALYSIS OF LWT AND WOLOF LOANS ACCORDING TO SEMANTIC FIELDS}

The analysis of the distribution of the borrowings based on semantic fields with regard to Tadmor's criteria shows that the most prolific semantic fields in borrowings are 'religion' (41.2\%), 'clothing' (38.6\%) and 'housing' (37.2\%). Intercultural influences are the main reason these authors put forward to explain such a reality. In the case of 'religions and beliefs' as a semantic field, they explain that the two great revealed religions, i.e. Christianity and Islam, have been adopted during their worldwide spread by people belonging to thousands of languages, and those populations consequently, have adopted the terminologies accompanying the two belief systems.

As for the semantic field of 'clothing', colonization and the impact of globalization have contributed a great deal to the adoption of a large number of words 
related to fashion that only developed countries knew before. It is the same with 'housing'. The explanation can be found in the switch from rural / rustic housing to global modern standards. The latter has had undoubtedly lexical consequences with exponential development of this sector throughout the world.

Addressing the issue of semantic fields which are least subject to borrowing such as 'body', 'kinship', 'spatial relations' and 'sense perceptions', representing only between $10-15 \%$, Tadmor notes that the universality of the concepts implies that languages do not really feel the need to import them. Table 10 summarizes the results obtained.

\begin{tabular}{ll}
\hline \multicolumn{1}{|c}{ TABLE 10: BORROWING BY SEMANTIC FIELD (TADMOR 64) } \\
\hline Religion and belief & $\%$ OF LOANWORDS \\
\hline Clothing and grooming & $41.2 \%$ \\
\hline The house & $38.6 \%$ \\
\hline Law & $37.2 \%$ \\
\hline Social and political relations & $34.3 \%$ \\
\hline Agriculture and vegetation & $31.0 \%$ \\
\hline Food and drink & $30.0 \%$ \\
\hline Warfare and hunting & $29.3 \%$ \\
\hline Possession & $27.9 \%$ \\
\hline Animals & $27.1 \%$ \\
\hline Cognition & $25.5 \%$ \\
\hline Basic actions and technology & $24.2 \%$ \\
\hline Time & $23.8 \%$ \\
\hline Speech and language & $23.2 \%$ \\
\hline Quantity & $22.3 \%$ \\
\hline Emotions and values & $20.5 \%$ \\
\hline The physical world & $19.9 \%$ \\
\hline Motion & $19.8 \%$ \\
\hline Kinship & $17.3 \%$ \\
\hline The body & $15.0 \%$ \\
\hline Spatial relations & $14.2 \%$ \\
\hline Sense perception & $14.0 \%$ \\
\hline Total & $11.0 \%$ \\
\hline & $\mathbf{2 4 . 2} \%$ \\
\hline
\end{tabular}

The comparison of semantic fields with the degree of loan functionality offers disparate results between the LWT project and Wolof. Indeed, with the exception of 'religion' and 'clothing', the semantic field most inclined to borrowing is 'time', by the large number of words that especially French (18.6\%) and Arabic (10.6\%) gave 
to the Wolof language. In the case of French, it is mainly young people and adults educated in this language, who use the terms relating to time such as the days of the week, the calendar months, the years (Arabic version is used by the elderly and the illiterate in French), the four seasons of the year (that the majority of Wolof speakers do not even know in Wolof) and several adverbs of time. Moreover, politics occupies such an important place in Senegalese social life that 'political and social relations' $(23.7 \%)$ gave more loans to the Wolof language than 'housing' $(21.8 \%)$ and 'animals' (8.2\%), for example.

The semantic field of 'animals' serves as a pretext for analyzing fields less inclined to borrowing. Indeed, according to Tadmor's results, apart from function words and semantic fields such as 'spatial relations' and 'perception of the senses', the semantic field of the 'body' (object of the second hypothesis), remains in general the field most reluctant to loans. However, in the case of Wolof, it is the semantic field of 'animals' with only $8.2 \%$ of borrowings which constitutes the field which gives the least borrowings to the Wolof language, compared to the $11.0 \%$ belonging to the semantic field of the 'body'. If this is so it is because, apart from animals living outside the Senegalese ecosystem, (almost) all other animals have their names or doublets in Wolof. Therefore, we can say that the second hypothesis is not confirmed, since the semantic field of the 'body' with $11.0 \%$ of the borrowings, gave the Wolof language a percentage higher than that of the 'animals' which remains at $8.2 \%$.

As for the third hypothesis stating that the terms referring to novelties (objects and new creations) are more inclined to be borrowed, it also remains confirmed, insofar as the semantic field of the 'modern world' with a percentage of $92.9 \%$ represents the field that produces the most borrowings among the 24 analyzed semantic fields. These new objects, in fact, represent totally unknown concepts in traditional Wolof, and their integration, in most cases, was carried out with a more or less important phonological adaptation and without any semantic or morphosyntactic change.

\begin{tabular}{|c|c|c|c|c|c|c|c|c|c|c|c|}
\hline SEMANTIC FIELDS & 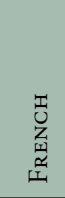 & 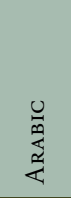 & 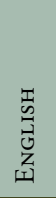 & 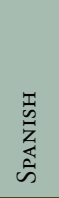 & 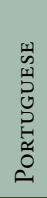 & 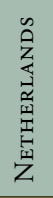 & 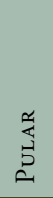 & 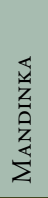 & 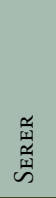 & 衣 & $\begin{array}{l}\text { Õ } \\
0 \\
0 \\
z \\
z \\
0 \\
0 \\
0 \\
z\end{array}$ \\
\hline Modern world & 92.6 & - & - & 0.3 & - & - & - & - & - & 2.9 & 7.1 \\
\hline Religion and belief & 10.9 & 35.8 & 0.1 & - & - & - & - & - & 0.8 & 47.6 & 52.4 \\
\hline $\begin{array}{l}\text { Clothing and } \\
\text { grooming }\end{array}$ & 24.0 & 6.4 & 1.1 & - & - & 1.7 & 1.0 & & - & 34.2 & 65.8 \\
\hline Time & 10.6 & 18.6 & 1.3 & - & - & - & 0.5 & - & - & 31.0 & 69.0 \\
\hline Food and drink & 16.7 & 10.7 & 1.2 & - & - & - & 0.7 & 0.1 & - & 29.4 & 70.6 \\
\hline $\begin{array}{l}\text { Social and political } \\
\text { relations }\end{array}$ & 19.7 & 3.6 & 0.4 & - & - & - & - & - & - & 23.7 & 76.3 \\
\hline
\end{tabular}




\begin{tabular}{|c|c|c|c|c|c|c|c|c|c|c|c|}
\hline Possession & 18.8 & 2.7 & 0.4 & - & - & - & - & 0.0 & - & 21.9 & 78.1 \\
\hline The house & 16.7 & 4.0 & 0.3 & - & 0.6 & - & - & 0.2 & - & 21.8 & 78.2 \\
\hline Cognition & 18.1 & 2.7 & 0.5 & - & - & - & - & - & - & 21.3 & 78.7 \\
\hline $\begin{array}{l}\text { Basic actions and } \\
\text { technology }\end{array}$ & 12.5 & 5.3 & 1.6 & - & 0.5 & - & - & 0.0 & - & 19.9 & 79.1 \\
\hline Quantity & 12.3 & 2.1 & 1.1 & - & 1.2 & 2.1 & 0.8 & 0.0 & - & 19.6 & 80.4 \\
\hline Motion & 14.4 & 2.7 & 1.1 & - & - & - & - & 0.1 & - & 18.3 & 81.7 \\
\hline $\begin{array}{l}\text { Emotions and } \\
\text { values }\end{array}$ & 9.8 & 6.2 & 0.3 & 1.0 & - & - & - & 0.0 & - & 17.3 & 82.7 \\
\hline Kinship & 10.0 & 5.5 & 0.3 & - & 0.2 & - & - & 0.1 & 0.2 & 16.3 & 83.7 \\
\hline The physical world & 11.9 & 4.0 & - & - & - & - & - & - & - & 15.9 & 84.1 \\
\hline Law & 8.7 & 6.0 & 0.2 & - & - & - & - & - & - & 14.9 & 85.1 \\
\hline $\begin{array}{l}\text { Speech and } \\
\text { language }\end{array}$ & 10.3 & 1.4 & 0.3 & - & - & - & - & - & - & 12.0 & 88.0 \\
\hline The body & 6.3 & 1.3 & 1.1 & - & 2.3 & - & - & & - & 11.0 & 89.0 \\
\hline $\begin{array}{l}\text { Warfare and } \\
\text { hunting }\end{array}$ & 8.7 & - & 0.3 & - & - & - & - & - & - & 9.0 & 91.0 \\
\hline $\begin{array}{l}\text { Agriculture and } \\
\text { vegetation }\end{array}$ & 6.2 & 2.0 & 0.1 & - & - & - & 0.6 & - & - & 8.9 & 91.1 \\
\hline Animals & 4.2 & 4.0 & - & - & - & - & - & - & - & 8.2 & 91.8 \\
\hline Sense perception & 5.6 & 2.4 & 0.1 & - & - & - & - & - & - & 8.1 & 91.8 \\
\hline Spatial relations & 2.3 & 0.7 & 1.5 & - & - & - & - & - & - & 4.5 & 95.5 \\
\hline Function words & 1.8 & - & - & - & 0.1 & - & - & - & - & 1.9 & 98.1 \\
\hline TOTAL & 15.0 & 5.3 & 0.5 & 0.0 & 0.2 & 0.0 & 0.1 & 0.0 & 0.0 & 21.1 & 78.9 \\
\hline
\end{tabular}

To the central question of why there is the need to import words from other languages if each language has in its own system mechanisms and "unlimited" techniques of lexical combination that allow it to name any novelty, be it abstract or physical, foreign or local, which were the findings? the answer must be understood in a double reading of the data that our analysis has revealed.

1. On the one hand, languages borrow words from other languages to fill a linguistic gap because of the rapid evolution of society, with the creation of new concepts related to new technologies. As far as Wolof is concerned, it is the semantic field of 'modern world' which gives most of the present borrowings with words such as partaaze, bëez, ójo, buwaat wokaal, konekte, cate, etc. Indeed, the Wolof speaker has integrated in his lexicon $92.9 \%$ of the borrowings of this semantic field.

2. On the other hand, the semantic domains of 'food and drink', 'clothing', 'home' and 'religion and beliefs' have enriched the Wolof lexicon not only linguistically but also culturally. In the area of 'food and drink', for example, borrowing (especially from French) has brought a new way of eating (furset, 
palaat, soos, buwaasoy, etc.); 'clothing,' a new way of dressing (pàntaloy, west, kostim, sipp, etc.); 'housing', a new way of life (taabal, fótóoy, làmp, miir, etaas, etc.); and 'religion and beliefs', a new way of believing (julli, jullite, nodd, naafila, xëdd, etc.).

\section{CONCLUSION}

After having compared the results obtained by the authors of the LWT project with those of the Wolof language, in order to verify the relevance, for Wolof, of the general principles of applicability of the resulting loans, we were able to verify the three research hypotheses, drawing the following conclusions:

- In both studies, names are easier to import than verbs: hypothesis confirmed.

- In both studies, the terms that designate 'novelties' (objects and new creations) are more inclined to borrowings: hypothesis confirmed.

- In the case of the LWT, the semantic field of the 'body' is the one that is the least inclined to borrow, while in the case of Wolof, it is that of 'animals': unconfirmed hypothesis.

Thus, the Wolof language vis-à-vis its borrowings does not differ from the languages studied by Haspelmath $\&$ Tadmor, thus reflecting the same universal typological model. 


\section{WORKS CITED}

Cissé, Mamadou. Dictionnaire Français-Wolof. L’Asiathèque-Maison des langues du monde: Paris, 2004

Diccionarios y léxicos. http://www.arabdict.com/ردق/ينابسإيبرع.

Diouf, Jean-Léopold. Dictionnaire Wolof-Français et Français-Qolof. Karthala: Paris, 2003.

Faidherbe, Louis Léon César. Langues Sénégalaises: Wolof, Arabe-hassania, Soninké, Sérère, Notions Grammaticales, Vocabulaires et Phrases. E. Leroux: Paris, 1887.

Dumont, Pierre. Le Français et Langues Africaines au Sénégal. Karthala: Paris, 1983.

Gamble, David Percy. Gambian Wolof-English Dictionary. Gambian Studies: Brisbane, California, 1991.

Haspelmath, Martin \& Tadmor, Uri. Loanwords in the World's Languages: A Comparative Handbook. Mouton Gruyter: Berlin / New York, 2009. 1-75.

Recensement Général de la Population et de l'Habitat, de l'Agriculture et de l'Elevage (RGPHAE 2013) http://www.ansd.sn/ressources/RGPHAE-2013/ressources/doc/ pdf/3.pdf.

TADMOR, Uri, 2009. "Loanwords in the World's languages: Findings and Results." Loanwords in the World's Languages: A Comparative Handbook. Ed. Martin Haspelmath and Turi Tadmor. Mouton Gruyter: Berlin / New York, 2009. 55-75.

Tнгам, Alioune Badara. Los préstamos lingüisticos en la lengua wolof: estudio tipológico. Tesis doctoral, ULL, La Laguna, España, 2016.

Triaud, J.L. "Senegal." Encyclopaedia of Islam. Ed. P. Bearman, Th. Bianquis, C.E. Bosworth, E. van Donzel and W.P. Heinrichs. Consulted online on 30th October 2019. http://dx.doi. org/10.1163. 
